\title{
PLASTIC MULCHING OR CONVENTIONAL CULTIVATION OF LAVENDER FLOWER: WHAT INFLUENCE ON THE YIELD, ESSENTIAL OIL AND THEIR NEUROPROTECTIVE EFFECTS?
}

\author{
Nazim Sekeroglu ${ }^{1,2 *}$, Gulfer Cimen ${ }^{3}$, Muhittin Kulak $^{4}$, Sevgi Gezici ${ }^{2,5}$ \\ ${ }^{1}$ Department of Horticulture, Faculty of Agriculture, Kilis 7 Aralik University, 79000 Kilis, TURKEY \\ ${ }^{2}$ Advanced Technology Application and Research Center, Kilis 7 Aralik University, 79000 Kilis, TURKEY \\ ${ }^{3}$ Department of Biology, Faculty of Science and Literature, Kilis 7 Aralik University, 79000, Kilis, TURKEY \\ ${ }^{4}$ Department of Herbal and Animal Production, Vocational School of Technical Sciences, Iğdir University, Iğdır, TURKEY \\ ${ }^{5}$ Department of Medical Biology and Genetics, Faculty of Medicine, Gaziantep University, 27300, Gaziantep, TURKEY
}

Cite this article as:

Sekeroglu N., Cimen G., Kulak M. \& Gezici S. 2022. Plastic mulching or conventional cultivation of lavender flower: What influence on the yield, essential oil and their neuroprotective effects? Trakya Univ J Nat Sci, 23(1): 43-52, DOI: 10.23902/trkjnat.992275

Received: 07 September 2021, Accepted: 15 December 2021, Online First: 28 January 2022, Published: 15 April 2022

Edited by:

Mehmet Bora Kaydan

*Corresponding Author:

Nazim Sekeroglu

sekeroglunazim@gmail.com

\section{ORCID iDs of the authors:}

NS. orcid.org/0000-0002-0630-0106

GC. orcid.org/0000-0002-1488-0243

MK. orcid.org/0000-0002-3673-9221

SG. orcid.org/0000-0002-4856-0221

Key words:

Lavandula angustifolia Mill

Terpenoids

Secondary metabolites

Medicinal and aromatic plants

Cosmetics

\begin{abstract}
Lavender (Lavandula angustifolia Mill.) flowers and its distilled products are of major raw materials for cosmetic, perfumery, medicine and cleaning industries. Lavender flower production, essential oils and their qualities are affected by growing conditions and used agricultural methods. Mulching is a cultural application used for horticultural production in order to combat weeds, keep the soil temperature constant, eliminate soil moisture evaporation, provide favourable growth conditions for ample flower production, and improve the quality essential oil production. In this sense, plastic mulch application is the mainly preferred method by the growers, due to its low costs and durability. In the present study, two-year field (20142015) studies were carried out to evaluate the lavender flower production, essential oil yield in both conventional (without mulch) and plastic mulching systems in city of Kilis-Turkey. The individual essential oil compounds were identified using Gas Chromatography-Mass Spectrometer (GC-MS). Essential oils obtained from dried flowers were assayed for their neuroprotective effects. According to the results, fresh and dry inflorescence yields, dry flower yields, flower essential oil contents and compositions were affected by different growing methods, including (1) plastic mulching system and (2) conventional (without mulch) system. Considering the fresh inflorescence changes, mulching increased the yield by $147.84 \%$ in the first year while no significant changes were noted between treatments. Interestingly, dry inflorescence yield did not show a significant increase for both growing systems at first year but mulching enhanced the yield by $9.87 \%$ in the second year, in related to the traditional treatment. The results revealed that dry flower was not affected by both growing systems corresponding to the years. As for essential oil content, no changes were noted for both growing systems in the first year, whilst mulching increased the content by $13.73 \%$ in the second year. As the case of agricultural yield, the neuroprotective activities of essential oils obtained from mulching conditions exerted higher inhibitory roles against Acetyl-cholinesterase (AChE), butyryl-cholinesterase (BChE), and tyrosinase (TYRO) enzymes, in relative to the traditional treatments by $81.62 \%, 84.12 \%, 73.34 \%$ in the first year and by $76.15 \%, 79.80 \%$ and $68.02 \%$ in the second year. Such a high variation in neuroprotective activities can be explained by changes in essential oil contents, as observed for the percentage of the compounds. Consequently, these findings reveal that mulching application significantly contributes to the increase of agricultural yield and the growing of medicinal and aromatic plants that are more resistant to changing environmental conditions and biotic stress factors.
\end{abstract}

Özet: Lavanta (Lavandula angustifolia Mill.) çiçekleri ve distile ürünleri kozmetik, parfümeri, ilaç ve temizlik endüstrilerinin başlıca hammaddesidir. Lavanta çiçeği üretimi, uçucu yağlar ve nitelikleri, yetiştirme koşullarından ve kullanılan tarım yöntemlerinden etkilenir. Malçlama, yabani otlarla mücadele etmek, toprak sıcaklığını sabit tutmak, topraktaki nem buharlaşmasını ortadan kaldırmak, bol çiçek üretimi için uygun büyüme koşullarını sağlamak ve kaliteli uçucu yağ üretimini iyileştirmek amacıyla bahçecilik üretiminde kullanılan kültürel bir uygulamadır. $\mathrm{Bu}$ anlamda plastik malç uygulaması, düşük maliyeti ve dayanıklılığı nedeniyle yetiştiriciler tarafından en çok tercih edilen yöntemdir. Bu çalışmada, Kilis ilinde hem geleneksel (malçsız) 
hem de malçlama sistemlerinde lavanta çiçeği üretimi, uçucu yağ veriminin değerlendirilmesi için iki yıllık (2014-2015) arazi çalışmaları yapılmıştır. Ayrı ayrı uçucu yağ bileşikleri, Gaz Kromatografisi-Kütle Spektrometresi (GC-MS) kullanılarak tanımlanmıştır. Elde edilen sonuçlara göre, taze ve kuru çiçeklenme verimleri, kuru çiçek verimleri, çiçek uçucu yağ içerikleri ve kompozisyonları (1) plastik malç sistemi (2) geleneksel (malç uygulamadan) sistem olmak üzere farklı yetiştirme yöntemlerinden etkilenmiştir. Taze çiçeklenme değişiklikleri göz önüne alındığında, malçlama ilk yılda verimi \%147.84 artırırken, uygulamalar arasında önemli bir farklılık belirlenmemiştir. İlginç bir şekilde, kuru çiçek verimi birinci yılda her iki yetiştirme yöntemi için de önemli bir artış göstermemiştir ancak malçlama ikinci yılda geleneksel uygulamalara göre verimi \%9.87 artırmıştır. Sonuçlar, kuru çiçeğin yıllara tekabül eden her iki yetiştirme yönteminden de etkilenmediğini ortaya koymuştur. Uçucu yağ içeriğine gelince, ilk yılda her iki yetiştirme yöntemi için de herhangi bir değişiklik görülmezken, ikinci yılda malçlama içeriği \%13.73 oranında artırmıştır. Tarımsal verimde olduğu gibi, malçlama uygulamalarından elde edilen uçucu yağların nöroprotektif aktiviteleri, geleneksel tedavilere kiyasla asetil-kolinesteraz (AChE), butiril-kolinesteraz (BChE) ve tirozinaz (TYRO) enzimlerine karşı daha yüksek inhibitör roller sergilemiştir. Birinci yılda $\% 81.62, \% 84.12, \% 73.34$ ve ikinci yılda $\% 76.15, \% 79.80$ ve $\% 68.02$ olarak gerçekleşmiştir. Nöroprotektif aktivitelerdeki bu kadar yüksek bir varyasyon, bileşiklerin yüzdesi için gözlemlendiği gibi, uçucu yağ içeriğindeki değişiklikleri ile de açılanabilir. Sonuç olarak bu bulgular, malçlama uygulamasının tarımsal verimin artmasına ve değişen çevre koşullarına ve biyotik stres faktörlerine daha dayanıklı tıbbi ve aromatik bitkilerin yetiştirilmesine önemli ölçüde katkı sağladığını ortaya koymaktadır.

\section{Introduction}

Lavender (Lavandula angustifolia Mill.) is one of the main aromatic plants used in a number of industries such as cosmetic, perfumery, medicine and cleaning. Although the main producers of lavender and lavender distillation products are France, Bulgaria, China, Russia and some other Eastern European countries (Giray 2018), Turkey, whose cultivation area is expanding may also be among these important suppliers (Tarhan et al. 2019). As a consequence of assessing lavender for alternative agriculture activities to the common activities, the existing production areas have decreased (Cimen 2016). Besides the decline from over-harvesting, lavender is widely cultivated in rural areas in infertile, sloping and dry fields (rain water). In order to provide a sustainable harvest and yield with desired bioactive contents for all industrial demands, special and appropriate production methods are required.

Mulching, one of the recently employed methods, is suitable for relevant areas regarding conserving water in soil since the severity, duration and frequency of water stress increase (Wada et al. 2011, Ranjan et al. 2017, Iqbal et al. 2020).In addition, it has been reported that in changing environmental conditions, especially in arid regions, higher irrigation quotas are needed for conventional agriculture, causing a significant conflict among the growers over the availability of water supply and in this context, the requirements for innovations in crop systems are emphasized (Yin et al. 2019).

The primary tasks in agricultural production increasing water use efficiency or effective utilization of water are of the major interests. For this reason, mulch applications have been extensively used in recent years, especially in developed countries (Ghosh et al. 2006, Chen et al. 2007, Braretet al. 2014, Kearney et al. 2017, Deng et al. 2019, Yang et al. 2019, Yin et al. 2019). Among mulching, organic mulches are commonly preferred because they are recyclable and environmentally friendly (Küçükyumuk \& Kelen 2006, Halbritter \& Wheeler 2019). Since organic mulch materials such as straw, hay, leaves, grass clippings, sawdust, crumbled bark and dry swamp moss are environmentally friendly and easily available; they are used especially in organic mulch application in organic farming systems. These materials are then mixed into the soil and allow the soil to be enriched with organic matter.

In addition, various plastic materials such as polyethylene and polyvinylchloride (PVC) and trellis (fabric, wool and woven ground cover) are used as inorganic mulch materials. Plastic mulch materials are in different colours (black, white, transparent, red, etc.) and removed from the field after being used (Trewavas 2001, Küçükyumuk \& Kelen 2006, Gezici 2018). For varieties of mulches, organic and synthetic mulches have been commonly used for vegetables, providing an effective barrier against weeds (Adamczewska-Sowinska \& Turczuk 2018). Additionally, the mulch applications cause significant results such as reduction in water loss and evaporation, and increasing in soil temperature (Wróblewska et al.2019). As reported by Mendonça et al. (2005), earlier crop growth and increased yield might be observed through mulch application.

In the case of medicinal and aromatic plant studies with the uses of mulches, increases in plant and essential oil yield of rosemary by 16.2 and $24.2 \%$, respectively, were noted, but the major composition of essential oil was not affected (Singh 2013). In case of black polyethylene mulch, higher flower yield coupled with good essential oil quality of damask rose was obtained (Thakur et al. 2019). Because the responses of plants against different light intensities are together dependent on climatic conditions and plant genotypes, further studies may be needed and customized for each plant species due to species-specific responses. Therefore, we aimed to investigate the impacts of polyethylene mulching on flowering and flower yield, essential oil composition, and neuroprotective activities in L. angustifolia comparing traditional cultivation method (no-mulching and control). 


\section{Materials and Methods}

Field experiments were conducted in the fields of Agricultural Application and Research Center of Kilis 7 Aralik University in Kilis, Turkey during the years of 2014 and 2015. The climate of the region is characterized as semi-arid with warm summer and mild winter. Monthly average temperatures in the relevant experimental region for January, February, April, September, and November in both years were relatively similar. Except the period of October and November, 2014 was slightly warmer than 2015 . The percentage of total rain fall was higher in 2015 , except for November and December periods (18.5 and $28.0 \mathrm{~mm}$, respectively). The average relative humidity varied between the months of both years.

The chemical characteristics of the experimental soil were as follows: $\mathrm{pH}=8.15$ (alkaline), organic content $2.1 \%$ (medium), calcium carbonate $\left(\mathrm{CaCO}_{3}\right)$ $47.49 \%$ (very calcareous), total salt $0.016 \%$ (low salt), available phosphorus (P, Olsen) $4.12 \mathrm{~kg} / \mathrm{ha}$ (low), available potassium (K) $136.00 \mathrm{~kg} / \mathrm{ha}$ (very high) and clay-loam.

\section{Plant materials and field experiment}

Seedlings were obtained from Kilis 7 Aralik University Agricultural Application and Research Centre (TUAM). According to the experimental design, main factor was the mulching treatment. In this regard, the research field was covered with the black plastic mulch (0.20 microns) for the mulching, whilst no-mulching was done for the control group (conventional/traditional method). Seedlings were planted in three replications in March 2014 in Split Plot Design in both plots with 50x100 $\mathrm{cm}$ row spacing between plants. Each plot had 32 lavender seedlings, and all the plots were irrigated with a drip irrigation system for three hours a day and three days a week during the vegetation period. Fresh inflorescences $(\mathrm{kg} / \mathrm{da})$ were harvested two times (June and August) a year in the first and second experimental years.

\section{Agricultural traits}

Fresh inflorescences, dried inflorescences, and dry flower yields $(\mathrm{kg} / \mathrm{da})$ of the plants were recorded for agricultural traits. Drying of the fresh inflorescences was achieved in the laboratory in well-ventilated shady places.

\section{Essential oil hydro-distillation extraction}

Essential oils were obtained from dried flowers by hydro-distillation using a Clevenger type apparatus. Essential oils were dried over anhydrous sodium sulfate, then filtrated and kept at $4^{\circ} \mathrm{C}$ for further chromatographic analysis (Filly et al. 2016).

\section{Essential oil component analysis by GC-MS}

Essential oil components were separated by diluting the obtained essential oil using 1/10 ratio of hexane. For determination of lavender essential oil compounds, Gas Chromatography-Mass Spectrometer (GC-MS) (7890A; Agilent Technologies) coupled with HP-5 Mass
Spectrometer (MS) capillary column (30 m x $0.25 \mu \mathrm{m} \mathrm{x}$ $250 \mu \mathrm{m})$ and $5975 \mathrm{C}$ (Agilent Technologies) inert mass selective detector was used. Also, electron ionization system with $70 \mathrm{eV}$ ionization energy and helium $(\mathrm{He})$ gas were used as a carrier gas. Flow rate was $1 \mathrm{~mL} / \mathrm{min}$. The MS transfer temperature was set to $250^{\circ} \mathrm{C}$, column temperature was first increased to $60^{\circ} \mathrm{C}$, then $5^{\circ} \mathrm{C} / \mathrm{min}$ to $200^{\circ} \mathrm{C}$ and kept isothermal for $5 \mathrm{~min}$ and eventually increased to $250^{\circ} \mathrm{Cat} 10^{\circ} \mathrm{C} / \mathrm{min} .1 .0 \mu \mathrm{L}$ of diluted samples $(1 / 100$ acetone, $v / v)$ were automatically injected into Split (50:1). The identification of the components was based on the comparison of retention times (RT) relative to nalkanes with matching spectra with those of W8N08, Wiley7n and Flavor2 (Baharum et al. 2010).

\section{Neuroprotective activity}

Acetyl-cholinesterase (AChE), butyryl-cholinesterase (BChE) and tyrosinase (TYRO) enzyme inhibition capacities were determined for neuroprotective potentials of essential oils of dry flowers. Essential oils were dissolved in dimethylsulfoxide (DMSO) at different concentrations beginning from $100 \mu \mathrm{g} \mathrm{mL}^{-1}$ and the final concentration of the essential oils was adjusted to $800 \mu \mathrm{g}$ $\mathrm{mL}^{-1}$. The percentage of enzyme inhibitions for AChE, BChE, and TYRO were calculated using the following equation:

\section{Enzyme inhibition $(\%)=[(C-S) / C \times 100]$}

Where $\mathrm{C}$ corresponds to absorbance of the control, $\mathrm{S}$ corresponds to absorbance of the tested sample (Ellman et al.1961).

\section{$\underline{A C h E}$ and BChE Inhibitory Activity}

$\mathrm{AChE}$ and BChE inhibitory activity of dry flower essential oils were measured with the slightly modified spectrophotometric method of Ellman et al. (1961). All reagents, conditions and calculations were same as described in previous studies (Senol et al. 2018, Gezici \& Sekeroglu, 2019). Galanthamine hydrobromide (Sigma, St. Louis, MO, USA) was employed as the reference anticholinesterase, and the final concentration of the reference was adjusted to $100 \mu \mathrm{g} \mathrm{mL}^{-1}$.

\section{TYRO Inhibitory Activity}

TYRO inhibition activity was tested according to the modified dopachrome method using L-DOPA as substrate (Sekeroglu et al. 2012, Gezici \& Sekeroglu 2021). $\alpha-$ Kojic acid (Sigma, St. Louis, MO, USA) was used as the reference, and the final concentrations of the tested samples and reference were adjusted to $800 \mu \mathrm{g} \mathrm{mL}^{-1}$ and $100 \mu \mathrm{g} \mathrm{mL}{ }^{-1}$, respectively.

\section{$\underline{\text { Statistical analysis }}$}

Three replications were used for each experiment. Data were expressed as mean. The means were compared using the one-way ANOVA followed by Duncan's multiple range tests using SPSS. The differences between individual means were considered statistically significant at $P<0.05$ and $P<0.01$. Pearson correlation analysis was performed among essential oil components identified. 


\section{Results and Discussion}

\section{Inflorescence and flower yields}

The mulching method provided significant increases in fresh flowering (28\%), dry flowering (27.8\%) and dried flower yields (14\%) when both years were considered in total. In the second year, however, mulching did not further affect significant increases in the yield, but the non-mulched control plants yielded approximately double fold in comparison to their firstyear harvests. Regarding the second year, fresh inflorescence $(\mathrm{kg} / \mathrm{da})$ values sharply increased from 33.95 to $163.11 \mathrm{~kg} / \mathrm{da}$ in non-mulching treatments, whereas the relevant values increased from 84.14 to $168.22 \mathrm{~kg} / \mathrm{da}$ in the mulch treatments. The relevant values of the treatments did not significantly vary corresponding to the treatment, as the similar case observed for dry inflorescence and dry flower (Table 1). As clearly can be seen, the non-mulched control plants nearly doubled fold. The increases might be attributed to the second year climatic vegetation. The relevant values of control reached a close those values of mulching, which can be also explained with the reported adverse impacts of plastic mulches such as pest infestation, microplastics contamination, soil puddling, soil structural loss (Amare \& Desta, 2021). Thus, the plants in the mulch gave more flower yield than in the conventional growing systems. This means that the mulch system could help plants to grow and produce more flowers. Therefore, there were large differences between the two growing systems in the first experimental year. Furthermore, the increases can be attributed to higher rainfall in the second year, which was almost double than that of the first year in both growing systems. Ricotta \& Masiunas (1991) presumably associated the higher yield with more rainfall and moderate temperatures. Similarly, Hoeberechts et al. (2004) noted significant increases in growth and weed control in lavender and rosemary plants under polyethylene and transpiring mulches in the first year, but the following year's data were not reported in the study. The increases also might be attributed to the root development of the plants, which provide more utilization of the soil nutrients (Tarara 2000, Sarrou et al. 2016). Because of limited mulching studies with the lavender, we were able to compare our findings with other medicinal plants. In these studies, fresh inflorescences of lavender were reported to vary between 205.01 and 820.40 kg/da (Özgüven et al. 2002 Kara \& Baydar 2012), which were relatively higher than the values of the present study. Lavender is a perennial plant and its economically yield begins in second or third year and the plants give yield up to 8-10 years. For that reason, the lower yield value reported in this study might be attributed to the harvest of the first two years. Concerning with mulch reports, black polyethylene mulching increased both fresh and dry yields in basil (Ocimum basilicum L.) and rosemary (Rosmarinus officinalis L.) (Ricotta \& Masiunas 1991). Also, plant growth and yield were enhanced in Melissa officinalis L. by mulching (Mendonça et al. 2005). Two clippings were made in $M$. officinalis and herewith the study, plant height and leaf yields were increased by the mulch. Also, the values were lowered in the second clipping. Faradonbeh et al. (2013) stated that mulching also positively affects the fresh weight and shoot dry matter yield of garlic.

\section{Essential oil results of dry flower}

The essential oil contents were not significantly affected by the mulch application in the first year, but in the second year, a slight increase $(13.73 \%$ ) was noted in the mulch treatment (Table 1). In accordance with the approximately double increases of the yield of inflorescence and flowers in non-mulched control, essential oil content also increased by $71.63 \%$ in comparison to those of the content of the first year. However, in those of mulch, essential oil content was not probably correlated with the yield of flower. In the case of lavender in the present study, mulch utilization did not exhibit large influence over the increasing of the essential oil contents.

Regarding theories for explaining the carbon and its allocation in constructing the secondary metabolites, as clearly and detailed presented in study by Szabó et al. (2020), there are many contrasts and conflicts between theories proposed due to the plant species, anatomical changes, carbon allocation through the cell etc. Along with the current work, we extracted and then analysed the oil for their content and compounds in inflorescences. The current findings regarding content and composition cannot be generalized to all essentialoil bearing plants, which likely to exhibit substantial variations. However, the results are consistent with the previous documents highlighting that essential oil content increase over years and reporting a range between 1.54\% and 9.62\% (Ozguven et al. 2002, Arabaci \& Bayram 2005, Kara \& Baydar 2012, Kara \& Baydar 2013). As also well-documented, the essential oil content and its chemical composition might also vary with the maturity of the plants (Telci et al. 2009, ElGamal \& Ahmed 2017).

Table 1. Change of yield and yield components in lavender according to different growing conditions.

\begin{tabular}{ccccc}
\hline \hline & \multicolumn{2}{c}{$\begin{array}{c}\text { Traditional (no } \\
\text { mulching) }\end{array}$} & \multicolumn{2}{c}{ Mulching } \\
\hline \hline & 1. Year & 2. Year & 1. Year & 2. Year \\
\hline $\begin{array}{c}\text { Fresh } \\
\text { inflorescence } \\
\text { (kg/da) }\end{array}$ & $33.95^{\mathrm{c}}$ & $163.11^{\mathrm{a}}$ & $84.14^{\mathrm{b}}$ & $168.22^{\mathrm{a}}$ \\
$\begin{array}{c}\text { Dry inflorescence } \\
\text { (kg/da) }\end{array}$ & $10.62^{\mathrm{b}}$ & $55.40^{\mathrm{a}}$ & $23.53^{\mathrm{b}}$ & $60.87^{\mathrm{a}}$ \\
$\begin{array}{c}\text { Dry flower } \\
\text { (kg/da) }\end{array}$ & $4.15^{\mathrm{b}}$ & $48.95^{\mathrm{a}}$ & $11.40^{\mathrm{b}}$ & $49.17^{\mathrm{a}}$ \\
$\begin{array}{c}\text { Essential oil } \\
\text { content (\%) }\end{array}$ & $4.37^{\mathrm{c}}$ & $7.50^{\mathrm{b}}$ & $4.53^{\mathrm{c}}$ & $8.53^{\mathrm{a}}$ \\
\hline \hline
\end{tabular}

Means in the same row by the same letter are not significantly different according to Duncan test $(\alpha=0.05)$. 
Table 2. Essential oil components identified from different growing conditions

\begin{tabular}{|c|c|c|c|c|c|c|c|}
\hline & & & & Control & & Mulching & \\
\hline No & Components & RT(min) & Area & 1. Year & 2. Year & 1. Year & 2. Year \\
\hline 1 & $\beta$-Thujene & 12.308 & 925.95 & nd & 0.15 & nd & nd \\
\hline 2 & $\alpha$-Pinene & 12.608 & 935.91 & nd & 0.81 & nd & 0.15 \\
\hline 3 & Camphene & 13.14 & 953.01 & nd & 0.58 & nd & 0.15 \\
\hline 4 & $\beta$-Pinene & 13.841 & 974.52 & nd & 0.52 & nd & 0.2 \\
\hline 5 & 3-Carene & 15.087 & 1011.70 & nd & 0.27 & nd & nd \\
\hline 6 & o-Cymene & 15.546 & 1025.93 & nd & 0.31 & nd & 0.16 \\
\hline 7 & Eucalyptol & 15.869 & 1035.69 & $12.58^{\mathrm{a}}$ & $14.50^{\mathrm{a}}$ & $8.9^{\mathrm{b}}$ & $12.04^{\mathrm{a}}$ \\
\hline 8 & $\beta$-Ocimene & 16.215 & 1045.94 & nd & 0.49 & nd & 0.22 \\
\hline 9 & $\gamma$-Terpinene & 16.701 & 1059.96 & nd & 0.23 & nd & nd \\
\hline 10 & p-2-Menthen-1-ol & 17.047 & 1069.70 & nd & nd & 0.55 & nd \\
\hline 11 & Bicyclo[3.1.0]hexane, & 17.057 & 1069.98 & nd & 0.52 & nd & nd \\
\hline 12 & Ethyl 2-(5-methyl-5-vinyltetr & 17.183 & 1073.48 & $4.07^{\mathrm{a}}$ & nd & $3.71^{\mathrm{b}}$ & nd \\
\hline 13 & Linalool oxide & 17.211 & 1074.25 & nd & nd & nd & 0.56 \\
\hline 14 & 6-Methyl-2-(2-oxiranyl)-5-hept & 17.725 & 1088.22 & $3.72^{\mathrm{a}}$ & nd & $3.52^{\mathrm{b}}$ & nd \\
\hline 15 & 1,6-Dihydrocarveol & 17.768 & 1089.37 & nd & 0.52 & nd & 0.31 \\
\hline 16 & Linalool & 18.769 & 1118.46 & $23.37^{\mathrm{c}}$ & $40.45^{\mathrm{b}}$ & $23.1^{\mathrm{c}}$ & $45.30^{\mathrm{a}}$ \\
\hline 17 & Neo-allo-ocimene & 19.228 & 1132.21 & nd & 0.69 & nd & 0.71 \\
\hline 18 & 2,6,6-Trimethylbicyclo[3.1.1] & 19.725 & 1146.74 & nd & nd & 0.5 & nd \\
\hline 19 & Camphor & 20.023 & 1155.27 & $25.91^{\mathrm{ab}}$ & $13.83^{\mathrm{b}}$ & $35.86^{\mathrm{a}}$ & $12.13^{\mathrm{b}}$ \\
\hline 20 & Lavandulol & 20.421 & 1166.47 & nd & 0.76 & 0.81 & 0.84 \\
\hline 21 & Borneol & 20.701 & 1174.23 & $10.12^{\mathrm{a}}$ & $6.39^{\mathrm{c}}$ & $9.43^{\mathrm{b}}$ & $5.88^{\mathrm{d}}$ \\
\hline 22 & 4-Terpineol & 21.362 & 1192.11 & $6.64^{\mathrm{b}}$ & $7.31^{\mathrm{b}}$ & $11.7^{\mathrm{a}}$ & $6.45^{\mathrm{b}}$ \\
\hline 23 & $\alpha$-Terpineol & 21.7 & 1201.27 & $2.59^{\mathrm{a}}$ & $1.30^{\mathrm{c}}$ & $2.58^{\mathrm{a}}$ & $1.50^{\mathrm{b}}$ \\
\hline 24 & Eucarvone & 22.199 & 1216.86 & nd & nd & 0.34 & nd \\
\hline 25 & Hexyl 2-methylbutyrate & 22.777 & 1234.49 & nd & 0.38 & nd & 0.24 \\
\hline 26 & Isobornylformate & 22.83 & 1236.08 & nd & 0.34 & nd & 0.21 \\
\hline 27 & Cumaldehyde & 23.268 & 1249.11 & nd & nd & nd & 0.13 \\
\hline 28 & Linalyl acetate & 23.359 & 1251.79 & nd & $3.28^{\mathrm{b}}$ & nd & $5.08^{\mathrm{a}}$ \\
\hline 29 & Lavandulol acetate & 24.497 & 1284.42 & nd & $1.00^{\mathrm{a}}$ & nd & $1.32^{\mathrm{a}}$ \\
\hline 30 & Hexyl-2-methylbut-2-enoate & 25.907 & 1327.26 & nd & 0.25 & nd & 0.15 \\
\hline 31 & Nerol acetate & 26.986 & 1360.72 & nd & 0.21 & nd & 0.17 \\
\hline 32 & 2,6-Dimethyl-2,6-octadien-8-yl acetate & 27.621 & 1379.79 & nd & 0.52 & nd & 0.26 \\
\hline 33 & $\alpha$-Bergamotene & 28.07 & 1393.02 & nd & 0.2 & nd & nd \\
\hline 34 & Santalen & 29.175 & 1428.96 & nd & 0.18 & nd & nd \\
\hline 35 & Caryophyllene & 29.42 & 1437.01 & nd & 0.65 & nd & 0.78 \\
\hline 36 & $\beta$-Farnesene & 30.098 & 1458.94 & nd & $2.34^{\mathrm{a}}$ & nd & $2.68^{\mathrm{a}}$ \\
\hline 37 & $\beta$-Cubebene & 31.296 & 1496.50 & nd & 0.45 & nd & 0.6 \\
\hline 38 & Butanoic acid, 2-methyl-, & 31.581 & 1506.07 & nd & $1.17^{\mathrm{a}}$ & nd & $1.17^{\mathrm{a}}$ \\
\hline 39 & Caryophyllene oxide & 34.448 & 1603.64 & nd & 0.53 & nd & 0.4 \\
\hline 40 & tau-Cadinol & 35.878 & 1655.54 & nd & 0.22 & nd & nd \\
\hline
\end{tabular}


In previous reports, mulch application increased essential oil ratio of different aromatic plants (Ricotta \&Masiunas 1991, Lafmajani \& Tabaei-Aghdaei 2012, Singh 2013, Silva et al. 2014, Braret al. 2014). However, no significant changes were reported for essential oil yield of damask rose (Mendonça et al. 2005, Thakur et al. 2019). Furthermore, type of mulching did not interfere in biomass and essential oil production in $M$. officinalis (Biasi et al. 2009).

\section{Essential oil components}

The essential oil components identified from different growing conditions are listed in Table 2. Along with the GC-MS analysis, 40 different components were identified. Eucalyptol, ethyl 2-(5-methyl-5vinyltetrahydrofuran-2-yl) propan-2-yl carbonate, linalool, camphor, borneol, 4-terpineol, $\alpha$-terpineol, linalyl acetate, lavandulol acetate, $\beta$-farnesene and butanoic acid 22-methyl-, 3,7-dimethyl-2,6-octadienyl ester were the major components obtained (Table 2). Of these compounds, the percentage of eucalyptol ranged from $8.9 \%$ to $14.50 \%$. During the both years, traditional (control) treatments exhibited higher eucalyptol percentages $(14.50 \%)$. However, differences in the second year were not significant between the treatments. In the study by Singh (2013), eucalyptol in the oil was not affected by the use of organic mulch in Rosmarinus officinalis L. As the case reported by Kulak (2020), eucalyptol content increased with the drought stress and maturity. We also observed similar findings in current work. The increases in eucalpytol might be explained with the soil water content, which is expected to be lower than the mulch applications. Along with the decline in the soil water content, eucalyptol synthesis was triggered in different aromatic plant species. Linalool content did not differ in the first year of the traditional and mulching treatments $(23.37 \%$ and $23.1 \%$, respectively), but in the second year, higher content was achieved in mulch plotted groups (45.30\%). The content was almost double in the second year in both treatments, suggesting that plant maturity increased the content. As reviewed by Chacón et al. (2013), the alterations in biochemical structure of the plants are dynamic and mostly dependent on expression levels of genes linked to the synthesis of the molecules. However, as the clearly known from proteomic reports, all related genes might not be translated to the final product due to the significant modifications or genetic regulations. In this context, the ahead studies should be addressed on molecular-directed approaches but being coupled with the basic physiological and biochemical assays (Kulak et al., 2019). In previous reports, linalool biosynthesis was also induced with mulching in Monarda didyma L. (Wróblewska et al. 2019) and Rosa damascene Mill (Thakur et al. 2019).

Camphor is one of the quality criteria of lavender essential oil and its concentration affects and deteriorates as the main components such as linalool and linalyl acetate (Kara \& Baydar 2013). The first-year values of camphor were about 2-3 folds times higher than second year values. In the first year, mulch plotted groups had higher values as $38.40 \%$ than the control group, but in the second year, treatments did not cause significant changes. Also, maturity of the plant caused significant reduction in the content of the camphor. Singh (2013) reported that organic mulching did not exhibit significant impacts on camphor in R. officinalis. As the report by Kulak (2020), the camphor content increased with the drought. In the control group of the current work, as we expected lower levels of soil water, lower levels of the relevant content were noted. We can explain this situation as that the declined soil water content due to high temperature and low levels of precipitation might no cause substantial decreases to be regarded/perceived as "stress". The second explanation might be linked to the "past episodes related to the stress" of the lavender plants. Furthermore, the maturity of the plants is also of the significant determinants in biosynthesis or their emissions. Accordingly, being correspondent with the current findings, we can suggest the new studies to be oriented on comprehensive parameters for partially clarifying the uncertainties.

Borneol content was higher for their content in the first year of conventional and mulching treatments ( $10.12 \%$ and $9.43 \%$, respectively) and decreased in the second year in both treatments $(6.36 \%$ and $5.88 \%$, respectively). Linalyl acetate in lavender oil is an essential oil component of perfumery industry and high linalyl acetate content is considered as an indicator of quality (Kara \& Baydar 2013). However, linalyl acetate was not detected in the essential oil composition of both groups for the first year.

According to the results of the previous studies regarding with lavender, linalool, linalyl acetate, camphor and borneol were the major components in essential oil (Arabaci \& Bayram 2005, Kara \& Baydar 2011, Kara \& Baydar 2012). The compounds identified in this study are similar to the previous studies, but varied in their percentages due to the treatments, climatic and soil factors. Changes in the essential oil yields might be attributed to biosynthetic activation of its pathways due to the photosynthetic light-mediated production of carbon chain (Fadil et al. 2016, Thakur et al. 2019). Furthermore, it has been well-documented and known that the percentages of components in essential oil are directly influenced by the genetic structure of the plant, age of the plant, plant parts, fresh or dry flower material, climate, soil and environmental conditions, applied agricultural methods and drying techniques. Also, availability of favourable soil temperature coupled with soil moisture might favour the secondary metabolites of essential oil crops (Fernandes et al. 2013, Thakur et al.2019; Thakur \&Kumar 2021).

\section{Correlations between essential oil components}

The correlation coefficients between the essential components identified along with the present study were given in Table 3 . The linalyl acetate component, which 
demonstrates the quality of lavender essential oil, was negatively correlated with ethyl 2-(5-methyl-5vinyltetrahydrofuran-2-yl) propan-2-yl carbonate, 3: 6Methyl-2- (2-oxiranyl) -5-hepten-2-ol, borneol and $\alpha$ terpineol. Also, linalyl acetate was positively correlated with linalool. According to the correlation analysis, there is a negative relationship between camphor, which negatively affects the quality of lavender essential oil, and linalool and linalyl acetate. As uttered above, camphor, in particular, is desired to be at a low content since its concentration the content of the main valued compound of lavender. However, the correlation analysis cannot be employed for a generalized deduction since it might be about "causation". Also, it is worth to note that the correlation coefficients are not constant but dynamic along with the developmental stage of the plants, harvesting time (diurnal) and environmental conditions.

\section{Neuroprotective potentials of dry flower essential oils}

The essential oils of dry flower were screened for their neuroprotective potentials through AChE, BChE, and TYRO enzymes using an ELISA micro plate reader at concentrations of 50,100, 200, 400 and $800 \mu \mathrm{g} \mathrm{mL}^{-1}$ (Table 4). The lavender EOs exhibited remarkable anticholinesterase and anti-tyrosinase enzyme activities, even at the lower concentrations, and the values were found to be statistically significant $(P<0.01$ and $P<0.001)$. However, the greatest enzyme inhibition was determined towards $\mathrm{BChE}$ enzyme (\% inhibition ranged from $84.12 \pm 0.09$ to $72.35 \pm 0.82$ ), while it was found the lowest against TYRO enzyme with the inhibition percentage varied from $61.58 \pm 0.15$ to $73.34 \pm 1.16 \%$ at $800 \mu \mathrm{g} \mathrm{mL}^{-1}$ concentrations. Consistent with the results of the agricultural treatment, EOs distilled from lavender grown under plastic mulching conditions exerted remarkable inhibition against AChE, BChE, and TYRO enzymes as compared to that of growing under the traditional system. The relevant values for mulching were $81.62 \%, 84.12 \%$, $73.34 \%$ in the first year and $76.15 \%, 79.80 \%, 68.02 \%$ in the second year. On the other hand, first year's harvest of lavender growing under plastic mulch or the traditional system caused much greater enzyme inhibitory effect against the tested enzymes than the second year's harvest (Table 4).

Table 3. Correlation coefficients between essential oil components

\begin{tabular}{ccccccccccccc}
\hline \hline Component & $\mathbf{1}$ & $\mathbf{2}$ & $\mathbf{3}$ & $\mathbf{4}$ & $\mathbf{5}$ & $\mathbf{6}$ & $\mathbf{7}$ & $\mathbf{8}$ & $\mathbf{9}$ & $\mathbf{1 0}$ & $\mathbf{1 1}$ & $\mathbf{1 2}$ \\
\hline \hline $\mathbf{1}$ & 1 & & & & & & & & & & \\
$\mathbf{2}$ & -0.52 & 1 & & & & & & & & \\
$\mathbf{3}$ & -0.54 & 1.00 & 1 & & & & & & & & \\
$\mathbf{4}$ & 0.52 & -0.97 & -0.97 & 1 & & & & & & & \\
$\mathbf{5}$ & -0.58 & 0.70 & 0.71 & -0.71 & 1 & & & & & & \\
$\mathbf{6}$ & -0.44 & 0.99 & 0.99 & -0.96 & 0.68 & 1 & & & & & \\
$\mathbf{7}$ & -0.82 & 0.46 & 0.48 & -0.54 & 0.62 & 0.42 & 1 & & & & \\
$\mathbf{8}$ & -0.58 & 0.99 & 0.99 & -0.95 & 0.71 & 0.95 & 0.48 & 1 & & & \\
$\mathbf{9}$ & 0.26 & -0.91 & -0.91 & 0.90 & -0.65 & -0.92 & -0.42 & -0.87 & 1 & & \\
$\mathbf{1 0}$ & 0.35 & -0.95 & -0.95 & 0.94 & -0.68 & -0.95 & -0.45 & -0.93 & 0.99 & 1 \\
$\mathbf{1 1}$ & 0.64 & -0.92 & -0.92 & 0.92 & -0.69 & -0.93 & -0.59 & -0.88 & 0.75 & 0.81 & 1 \\
$\mathbf{1 2}$ & 0.58 & -0.98 & -0.98 & 0.98 & -0.72 & -0.98 & -0.56 & -0.95 & 0.87 & 0.92 & 0.97 & 1 \\
\hline \hline
\end{tabular}

1: Eucalyptol; 2: Ethyl 2-(5-methyl-5-vinyltetrahydrofuran-2-yl) propan-2-yl carbonate; 3: 6-Methyl-2-(2-oxiranyl)-5-hepten-2-ol 4: Linalool; 5: Camphor; 6: Borneol; 7: 4-Terpineol; 8: $\alpha$-Terpineol; 9:Linalyl acetate; 10:Lavandulyl acetate; 11: $\beta$-Farnesene; 12:Butanoic acid, 2-methyl-, 3,7-dimethyl-2,6-octadienyl ester.

Table 4. Neuroprotective potentials of the lavender EOs against AChE, BChE, and TYRO at $800 \mu \mathrm{g} \mathrm{mL}{ }^{-1}$

\begin{tabular}{|c|c|c|c|}
\hline Lavender EOs $^{\mathrm{a}}$ & $\begin{array}{l}\text { Acetylcholinesterase }(\mathrm{AChE}) \\
\quad(\text { Inhibition } \% \pm \mathrm{SD})\end{array}$ & $\begin{array}{l}\text { Butyrylcolinesterase }(\mathrm{BChE}) \\
\text { (Inhibition \% } \% \text { SD) }\end{array}$ & $\begin{array}{c}\text { Tyrosinase } \\
\text { (TYRO) } \\
(\text { Inhibition \% } \pm \text { SD) }\end{array}$ \\
\hline T-1 & $70.50 \pm 0.16^{* * *}$ & $76.14 \pm 1.57^{* *}$ & $64.25 \pm 0.04 * * *$ \\
\hline T-2 & $68.47 \pm 0.08^{* *}$ & $72.35 \pm 0.82 * * *$ & $61.58 \pm 0.15^{* * *}$ \\
\hline M-1 & $81.62 \pm 0.50^{* *}$ & $84.12 \pm 0.09 * * *$ & $73.34 \pm 1.16^{* * *}$ \\
\hline M-2 & $76.15 \pm 1.04 * * *$ & $79.80 \pm 1.12 * * *$ & $68.02 \pm 1.08 * *$ \\
\hline GALA $^{b}$ & $87.06 \pm 0.28$ & $83.50 \pm 0.04$ & --- \\
\hline$\alpha-K A^{c}$ & --- & --- & $74.12 \pm 1.02$ \\
\hline
\end{tabular}


The present findings were compatible with previous studies reporting and revealing the impacts of growing conditions, different cultivars, and climatic conditions on the essential oil composition (Hancianu et al. 2013, Ayaz et al. 2017, Coelho et al. 2017). The potent inhibitory properties of lavender EOs could be attributed to linalool, linalyl acetate, camphor and borneol as revealed by previous reports (Ricotta \& Masiunas 1991, Mendonça et al. 2005). Despite the multi-factorial therapeutic approaches of neurodegenerative diseases, cholinergicbased therapy has become one of the most current approaches recently. Indeed, cholinesterase inhibition is the major treatment for the symptoms of Alzheimer's disease (AD). AChE and $\mathrm{BChE}$ are sister enzymes responsible for regulation of cholinergic transmission in the brain. The inhibition of these sister enzymes via natural products derived from medicinal and aromatic plants have been considered as a new and effective approach to mediate the progression of $\mathrm{AD}$ (Tundis et al. 2016, Gezici \& Sekeroglu 2019). As for TYRO enzyme, it is a major enzyme involved in catalysing the ohydroxylation of tyrosine to 3,4-dihydroxyphenylalanine or DOPA, which has been linked to Parkinson's disease (PD) pathogenesis. Similarly, the inhibition of TYRO enzyme has mostly been related to PD progression (Asanuma et al. 2003).

\section{Conclusion}

In conclusion, the plastic mulch application had a positive effect on lavender fresh inflorescence, dry inflorescence and dry flower yields in the first experimental year. However, during the second year, investigated yield parameters did not significantly change with the mulching, while non-mulched plotted groups of the plants increased the relevant parameters. These increases in the yields can be attributed to higher rainfall and moderate temperatures during the second year in the experimental area. In the case of essential oil contents, mulching adversely affected the percentage of eucalyptol and borneol, but increased linalool and linalyl acetate. The

\section{References}

1. Adamczewska-Sowinska, K. \& Turczuk, J. 2018. Effects of plastic and biodegradable mulch films in field tomato cultivation. Acta Scientiarum Polonorum Hortorum Cultus, 17: 123-133.

2. Amare, G. \& Desta, B. 2021. Coloured plastic mulches: impact on soil properties and crop productivity. Chemical and Biological Technologies in Agriculture, 8(1): 1-9.

3. Arabaci, O. \& Bayram, E. 2005. Aydın ekolojik koşullarında lavanta (Lavandula angustifolia Mill.)' nın bazı agronomic ve kalite özellikleri üzerine bitki sıklı̆̆ ve azotlu gübrenin etkisi. ADÜ Ziraat Fakültesi Dergisi, 2:13-19.

4. Asanuma, M., Miyazaki, I. \& Ogawa, N. 2003. Dopamineor L-DOPA-induced neurotoxicity: the role of dopamine quinone formation and tyrosinase in a model of Parkinson's disease. Neurotoicology Research, 5: 165-176. percentage of camphor was augmented by mulching in the first year; however, the percentage of the compound decreased in the second year. Furthermore, for assessment regarding neuroprotective potentials, essential oils distilled from dried flowers of lavender grown under mulching conditions exhibited remarkable inhibition against the tested enzymes as compared to that of plants growing under the traditional system. To the best of our literature survey, this research conducted to reveal the effects of harvest year and growing conditions on agricultural and neuroprotective properties and essential oil composition of lavender could be the first for the literature. The authors suggest that further biological activity analyses should be carried out to ascertain the slightly changes in agricultural properties and essential oil contents of lavender, which were found to be significantly higher in plastic mulching treatments than in conventional systems. Current findings demonstrated that mulching exerts remarkable biological activities coupled with agricultural yield and essential oil yield, suggesting the uses of mulching for growing the medicinal and aromatic plants in response to varying environmental conditions and biotic stresses.

Ethics Committee Approval: Since the article does not contain any studies with human or animal subject, its approval to the ethics committee was not required.

Author Contributions: Concept: N.S., Desing: N.S., Execution: N.S., S.G., Material supplying: N.S., G.C., Data acquisition: N.S., G.C., M.K., S.G., Data analysis/interpretation: G.C., M.K., S.G., Writing: N.S., M.K., S.G., Critical review: N.S.

Conflict of Interest: The authors have no conflicts of interest to declare.

Funding: The study was supported by the Kilis 7 Aralik University Scientific Research and Projects Unit (BAP) with the project number 2014/02/LTP/03.

5. Ayaz, M., Sadiq, A., Junaid, M., Ullah, F., Subhan, F. \& Ahmed, J. 2017. Neuroprotective and anti-aging potentials of essential oils from aromatic and medicinal plants. Frontiers in Aging Neuroscience, 9 (168): 1-16. https://doi.org/10.3389/fnagi.2017.00168

6. Baharum, S.N., Bunawan, H., Ghani, M.A.A., Mustapha, W.A.W. \& Noor, N.M. 2010. Analysis of the chemical composition of the essential oil of Polygonum minus Huds. Using two-dimensional gas chromatography-time-of-flight mass spectrometry (GC-TOF MS). Molecules. 15(10): 7006-7015.

7. Biasi, L. A., Kowalski, A. P. D. J., Signor, D., Alves, M. A., de Lima, F. I. \& Deschamps, C. 2009. Types of mulching and harvesting time on lemon balm production. Horticultura Brasileira, 27: 314-318. 
8. Brar, S.K., Gill, B.S., Brar, A.S. \& Kaur, T. 2014. Planting date and Straw mulch affect biomass yield, oil yield and oil quality of Japanese mint (Mentha arvensis L.) harvested at successive intervals. Journal of Essent Oil Bearing, Plants, 17(4): 676-695. http://dx.doi.org/10.1080/0972060X.2014.958549

9. Chacón, I. D. L. C., Riley-Saldaña, C. A., \& GonzálezEsquinca, A. R. (2013). Secondary metabolites during early development in plants. Phytochemistry reviews, 12(1): 47-64.

10. Chen, S.Y., Zhang, X.Y., Pei, D., Sun, H.Y. \& Chen, S.L. 2007. Effects of straw mulching on soil temperature, evaporation and yield of winter wheat: Field experiments on the North China Plain. Annals of Applied Biology, 150: 261268.

11. Çimen, G. 2016. Lavantanın çiçek verimi ve uçucu yağ bileşenlerine malç uygulamasının etkisi / Effect of mulching on the flower yield and essential oil composition, MSc thesis, Kilis 7 Aralik University, 42 pp.

12. Coelho, L.S., Correa-Netto, N.F., Masukawa, M.Y., Lima, A.C., Maluf, S., Linardi, A. \& Santos-Junior, J.G. 2017. Inhaled Lavandula angustifolia essential oil inhibits consolidation of contextual-but not tone-fear conditioning in rats. Journal of Ethnopharmacology, 215; 34-41.

13. Deng, H.L., Xiong, Y. C., Zhang, H.J., Li, F. Q., Zhou, H., Wang, Y.C. \& Deng, Z.R. 2019. Maize productivity and soil properties in the Loess Plateau in response to ridgefurrow cultivation with polyethylene and straw mulch. Science Report 9, 3090. https://doi.org/10.1038/s41598019-39637-w

14. El-Gamal, S. \& Ahmed, H. M. I. 2017. Influence of Different Maturity Stages on Fruit Yield and Essential Oil Content of Some Apiaceae Family Plants B: Fennel (Foeniculu mvulgare Mill.). Journal of Plant Production, 8(1). 127-133.

15. Ellman, G.L., Courtney, K.D., Andres Jr, V. \& Featherstone, R.M. 1961. A new and rapid colorimetric determination of acetylcholinesterase activity. Biochemistry Pharmacology, 7: 88-95. https://doi.org/10.1016/0006-2952(61)90145-9

16. Fadil, M., Farah, A., Ihssane, B., Haloui, T., Lebrazi, S., Zghari, B., et al. 2016. Chemometric investigation of lightshade effects on essential oil yield and morphology of Moroccan Myrtus communis L. Springer Plus. 5:1-14. https://doi.org/10.1186/s40064-015-1659-2

17. Faradonbeh, M.M., Mashhadi, A.A., Bakhshandeh, A. \& Jalal-abadi, A.L. 2013. Evaluation of the effects of different mulch material on quantity and quality yield of garlic populations (Allium sativum L.). International Journal of Agriculture and Crop Sciences, 5: 2660-2665.

18. Fernandes VF, de-Almeida LB, Feijo EVIRS, Silva DC, Oliveira RA, Mielke MS, et al. 2013. Light intensity on growth, leaf, micromorphology and essential oil production of Ocimum gratissimum. Brazilian Journal of Pharmaceutical Sciences, 23: 419-424.

19. Filly, A., Fabiano-Tixier, A. S., Louis, C., Fernandez, X. \& Chemat, F. 2016. Water as a green solvent combined with different techniques for extraction of essential oil from lavender flowers. Comptes Rendus Chimie, 19(6): 707-717.
20. Gezici S. \& Sekeroglu, N. 2019. Neuroprotective potential and phytochemical composition of acorn fruits. Industrial Crops and Products, 128: 13-17. https://doi.org/10.1016/j.indcrop.2018.10.082

21. Gezici, S. \& Sekeroglu, N. 2021. Comparative biological analyses on kenger and kenger coffee as novel functional food products. Journal of Food Science and Technology, 1-11.

22. Gezici, S. 2018. Promising anticancer activity of lavender (Lavandula angustifolia Mill.) Essential oil through induction of both apoptosis and necrosis. Annals of Phytomedicine, 7: 38-45. https://doi.org/10.21276/ap.2018.7.2.5

23. Ghosh, P.K., Dayal, D., Bandyopadhyay, K.K. \& Mohanty, M. 2016. Evaluation of straw and polythene mulch for enhancing productivity of irrigated summer groundnut. Field Crop Research, 99: 76-86.

24. Giray, F.H. 2018. An Analysis of World Lavender Oil Markets and Lessons for Turkey. Journal of Essential Oil Bearing Plants, 21(6): 1612-1623. https://doi.org/10.1080/0972060X.2019.1574612

25. Halbritter, D.A. \& Wheeler, G.S. 2019. Organic mulch can increase the survival of a weed biological control agent during laboratory mass rearing. Biocontrol Science and Technology. 1-8.

26. Hancianu, M., Cioanca, O., Mihasan, M. \& Hritcu, L. 2013. Neuroprotective effects of inhaled lavender oil on scopolamine-induced dementia via anti-oxidative activities in rats. Phytomedicine, 20: 446-452. https://doi.org/10.1016/j.phymed.2012.12.005

27. Hoeberechts, J., Nicola, S. \& Fontana, E. 2004. Growth of lavender (Lavandula officinalis) and rosemary (Rosmarinus officinalis) in response to different mulches. Acta Horticulturae, 649: 245-251.

28. Iqbal, R., Raza, M. A. S., Valipour, M., Saleem, M. F., Zaheer, M. S., Ahmad, S., Toleikiene, M., Haider, I., Aslam, M.U. \& Nazar, M. A. 2020. Potential agricultural and environmental benefits of mulches-a review. Bulletin of the National Research Centre, 44: 1-16.

29. Kara, N. \& Baydar, H. 2013. Determination of lavender and lavandin cultivars (Lavandula sp.) containing high quality essential oil in Isparta, Turkey. Turkish Journal of Field Crops, 18(1): 58-65.

30. Kara, N. \& Baydar, H. 2012. Essential oil contents and composition of lavenders and lavandins cultivated in Turkey. Research on Crops, 13(2): 675-681.

31. Kara, N. \& Baydar, H. 2013. Determination of lavender and lavandin cultivars (Lavandula sp.) containing high quality essential oil in Isparta, Turkey. Turkish Journal of Field Crops, 18: 58-65.

32. Kara, N. \& H. Baydar. 2011. Essential oil characteristics of lavandins (Lavandula $\mathrm{x}$ intermedia emeric ex loisel.) of Isparta province, kuyucak district, where lavender production center of Turkey. Journal of Selcuk Agricultre and Food Sciences, 25(4): 41-45.

33. Kearney, S.P., Fonte, S.J., García, E., Siles, P., Chan, K.M.A. \& Smukler, S.M. 2019. Evaluating ecosystem service trade-offs and synergies from slash-and-mulch agroforestry systems in El Salvador. Ecological Indicators, 105: 264-278. 
34. Küçükyumuk, C. \& Kelen, M., 2006. Organik tarımda malç kullanımı, pp. 1-4. Paper presented at the Türkiye III. Organik Tarım Sempozyumu, 1-3 November, YalovaTurkey.

35. Kulak, M., Ozkan, A. \& Bindak, R. 2019. A bibliometric analysis of the essential oil-bearing plants exposed to the water stress: How long way we have come and how much further? Scientia Horticulturae, 246: 418-436.

36. Kulak, M. 2020. Recurrent drought stress effects on essential oil profile of Lamiaceae plants: An approach regarding stress memory. Industrial Crops and Products, 154: 112695 .

37. Lafmajani, Z.N. \& Tabaei-Aghdaei, S.R. 2012. Studying the essential oil of some damask rose genotypes under dry farming and irrigated conditions. Annals of Biological Research, 3: 3037-3042.

38. Mendonça, M.C., Santos, M.F., Simões, R.A., Silva-Mann, R. \& Blank, A.F. 2005. Production and entomofauna associated to lemon balm (Melissa officinalis $\mathrm{L}$.) cultivated with synthetic mulch. Revista Brasileira de Plantas Medicinais Botucatu, 8: 63-67.

39. Ozguven, M., Kirpik, M. \& Sekeroglu, N. 2002. Determination of the optimal sowing time and nitrogen fertilization for lavender (Lavandula angustifolia Mill.) in the Çukurova conditions. pp. 217-223. Paper presented at the Workshop on Agricultural and Quality Aspects of Medicinal and Aromatic Plants, 29 May-01 June, AdanaTurkey.

40. Ranjan, P., Patle, G. T., Prem, M. \& Solanke, K. R. 2017. Organic mulching-A water saving technique to increase the production of fruits and vegetables. Current Agriculture Research Journal, 5(3): 371-380.

41. Ricotta, J.A. \& Masiunas, J.B. 1991. The effects of black plastic mulch and weed control strategies on herb yield. Hortscience, 26: 539-541.

42. Sarrou, E., Chatzopoulou, P., Koutsos, T. V. \& Katsiotis, S. 2016. Herbage yield and essential oil composition of sweet basil (Ocimum basilicum L.) under the influence of different mulching materials and fertilizers. Journal of Medical Plants Studies, 4(1): 111-117.

43. Sekeroglu, N., Senol, F.S., Orhan, I.E., Gulpinar, A.R., Kartal, M. \& Sener, B. 2012. In vitro prospective effects of various traditional herbal coffees consumed in Anatolia linked to neurodegeneration. Food Research International, 45(1): 197-203.

44. Senol F.S., Sekeroglu, N., Gezici S., Kilic E. \& Erdogan Orhan, I. 2018. Neuroprotective potential of the fruit (acorn) from Quercus coccifera L. Turkish Journal of Agriculture and Forestry, 42(2): 82-87.

45. Silva, A.C., Blank, A.F., Melo dos Santos, W., Prata, P.S., Alves, P.B. \& Arrigoni-Blank, M.F. 2014. Fertilization and colours of plastic mulch affect biomass and essential oil of sweet-scented geranium. The Scientific World Journal, 1-7.
46. Singh, M. 2013. Influence of organic mulching and nitrogen application on essential oil yield and nitrogen use efficiency of rosemary (Rosmarinus officinalis L.). Archives of Agronomy Soil Sciences, 59: 273-279.

47. Szabó, K., Zubay, P., \& Németh-Zámboriné, É. 2020. What shapes our knowledge of the relationship between water deficiency stress and plant volatiles? Acta Physiologiae Plantarum, 42(8): 1-11.

48. Tarara, J. M. 2000. Microclimate modification with plastic mulch. Horticultures Science, 35(2): 169-180.

49. Tarhan, Y., Aciksoz, S. \& Celik, D. 2019. Lavanta tarımı ve sürdürülebilir kalkınma: Isparta/Keçiborlu-Kuyucak Köyü örneği. Bartın University International Journal of Natural and Applied Sciences, 2(2): 216-227.

50. Telci, I., Demirtas, I. \& Sahin, A. 2009. Variation in plant properties and essential oil composition of sweet fennel (Foeniculum vulgare Mill.) fruits during stages of maturity. Industrial Crops and Products, 30(1): 126-130.

51. Thakur, M. \& Kumar, R. 2021. Mulching: Boosting crop productivity and improving soil environment in herbal plants. Journal of Applied Research on Medicinal and Aromatic Plants, 20: 100287.

52. Thakur, M., Bhatt, V. \& Kumar, R. 2019. Effect of shade level and mulch type on growth, yield and essential oil composition of damask rose (Rosa damascena Mill.) under mid hill conditions of Western Himalayas. PloS one, 14(4): $\mathrm{e} 0214672$.

53. Trewavas, A. 2001. Urban myths of organic farming. Nature. 410: 409-410.

54. Tundis, R., Bonesi, M., Menichini, F. \& R Loizzo, M. 2016. Recent knowledge on medicinal plants as source of cholinesterase inhibitors for the treatment of dementia. Mini-Reviews in Medicinal Chemistry, 16(8): 605-618.

55. Wada, Y., Van Beek, L. P. H., Viviroli, D., Dürr, H. H., Weingartner, R. \& Bierkens, M. F. 2011. Global monthly water stress: 2. Water demand and severity of water stress. Water Resources Research, 47(7): 1-17.

56. Wróblewska, K., Szumny, A., Żarowska, B., Kromer, K., Dębicz, R. \& Fabian, S. 2019. Impact of mulching on growth essential oil composition and its biological activity in Monarda didyma L. Industrial Crops and Products, 129: 299-308.

57. Yang, J., Zhang, T., Zhang, R., Huang, Q. \& Li, H. 2019. Long-term cover cropping seasonally affects soil microbial carbon metabolism in an apple orchard. Bioengineered, 10: 207-217.

58. Yin, W., Fan, Z., Hu, F., Yu, A., Zhao, C., Chai, Q. \& Coulter, J.A. 2019. Innovation in alternate mulch with straw and plastic management bolsters yield and water use efficiency in wheat-maize intercropping in arid conditions. Scientific Reports, 9(1): 1-14. 